\title{
Rancang Bangun Sistem Pakar Mendiagnosa Penyakit Tanaman Kelapa Sawit Menggunakan Metode Bayes Berbasis Android (Studi Kasus : Perkebunan PTPN 4 Air Batu)
}

\author{
Muhammad Dedi Irawan ${ }^{1}$, Muhammad Khairi Ikhsan Nasution ${ }^{2}$ \\ ${ }^{1,2,3}$ Program Studi Teknik Informatika, Fakultas Teknik Universitas Asahan \\ Jl Jend.Ahmad Yani, Kisaran, Sumatera Utara 21216, Indonesia \\ 1temansejati.dedi@gmail.com, 2khairiikhsan123@gmail.com
}

\begin{abstract}
Abstrak - PT. Perkebunan Nusantara IV Air Batu (PTPN IV) merupakan perkebunan kelapa sawit milik pemerintah yang bergerak dalam produksi buah sawit, tanaman kelapa sawit akan tumbuh dengan baik dan berproduksi secara optimal apabila tanaman tersebut dilindungi dari penyakit. Namun terjadi ketidak seimbangan dimana setiap tahun kebutuhan kelapa sawit semakin meningkat, sedangkan produksi kelapa sawit semakin menurun. Hal ini disebabkan kurang pahamanya asisten perkebunan terhadap jenis-jenis penyakit yang terdapat pada tanaman kelapa sawit yang dapat mengakibatkan kerusakan terus menerus pada tanaman kelapa sawit. Metode bayes merupakan salah satu metode yang cocok dalam penyeleksian, karena metode bayes ini merupakan metode yang baik didalam mesin pembelajaran berdasarkan data training dengan menggunakan probabilitas bersyarat sebagai dasarnya. Dengan adanya sistem pakar ini diharapkan asisten perkebunan dapat mengetahui jenis penyakit dan solusinya secara cepat sehingga masalah menurunnya produksi kelapa sawit dapat teratasi. Hasil dari penelitian berupa sistem pakar mendiagnosa penyakit tanaman kelapa sawit menggunakan metode bayes berbasis android dengan demikian, aplikasi ini dapat digunakan untuk melakukan analisa penyakit dengan menggunakan telepon selular.
\end{abstract}

Kata Kunci - Penyakit kelapa sawit, Sistem Pakar, Metode Bayes, Android.

\section{PENDAHULUAN}

Seiring dengan berkembangnya teknologi yang sangat pesat di masa ini, media komunikasi dan informasi semakin banyak memberikan kemudahan untuk saling berinteraksi antar pengguna. Dalam hal ini, handphone merupakan salah satu bentuk dari perkembangan teknologi yang tidak hanya berguna sebagai alat komunikasi, tetapi juga sebagai hiburan dan media pembelajaran. Fakta ini dapat dibuktikan dengan berkembangnya berbagai jenis smartphone yang dibuat vendor-vendor ponsel terkemuka di dunia. Hal ini baik secara langsung maupun tidak langsung berpengaruh terhadap perkembangan dunia pendidikan di Indonesia, dalam mengembangkan berbagai macam teknologi.

Penyakit tanaman kelapa sawit bisa dikatakan hal yang wajar karena penyakit atau hama bisa saja menyerang tumbuh-tumbuhan yang hidup di sekeliling kita, namun yang terpenting adalah bagaimana kita dapat menyelesaikan masalah pengendalian penyakit tersebut melalui penelitian ini peneliti melakukan pengumpulan data gejala-gejala yang dialami tanaman kelapa sawit untuk menganalisa tentang penyakit apa yang menyerang tanaman kelapa sawit selanjutnya peneliti melakukan diagnosa terhadap gejala-gejala yang dialami oleh tanaman kelapa sawit untuk mendapatkan hasil kesimpulan penyakit peneliti menggunakan metode bayes dalam mendiagnosa penyakit tersebut karena metode bayes merupakan sebuah teorema dengan dua penafsiran berbeda.

Dalampenafsiran Bayes, teorema ini menyatakan seberapa jauh derajat kepercayaan subjektif harus berubah secara rasional ketika ada petunjuk baru. Dalam penafsiran frekuentis teorema ini menjelaskan representasi invers probabilitas dua kejadian.

\section{LANDASAN TEORI}

\section{A. Sistem Pakar}

Secara umum, sistem pakar adalah sistem yang berusaha mengadopsi pengetahuan manusia ke komputer yang dirancang untuk memodelkan kemampuan menyelesaikan masalah seperti layaknya seorang pakar. Dengan sistem pakar ini, orang awam pun dapat menyelesaikan masalahnya atau hanya sekedar mencari suatu informasi berkualitas yang sebenarnya hanya dapat diperoleh dengan bantuan para ahli di bidangnya.

Sistem pakar ini juga akan dapat membantu aktivitas para pakar sebagai asisten yang berpengalaman dan mempunyai asisten yang berpengalaman dan mempunyai pengetahuan yang dibutuhkan. Dalam penyusunannya, sistem pakar mengkombinasikan kaidah-kaidah penarikan kesimpulan (inference rules) dengan basis pengetahuan tertentu yang diberikan oleh satu atau lebih pakar dalam bidang tertentu. Kombinasi dari kedua hal tersebut disimpan dalam komputer, yang selanjutnya digunakan dalam proses pengambilan keputusan untuk penyelesaian masalah tertentu (Siti Mujilahwati,2014).

Menurut T. Sutojo (Eli Rosmita Ritonga dan Muhammad Dedi Irawan, 2017) Sistem pakar adalah suatu sistem yang dirancang untuk dapat untuk dapat menirukan seorang pakar dalam menjawab pertanyaan dan memecahkan suatu masalah.

Menurut Acihmah Sidauruk dan Ade Pujianto, (2017) Sistem pakar adalah sistem yang berusaha mengadopsi pengetahuan manusia (Pakar) ke komputer, sehingga komputer dapat menyelesaikan permasalahan tersebut layaknya seorang pakar. Sampai saat ini sudah banyak sistem pakar yang dibuat. Kemampuannya untuk memberikan keputusan seperti seorang pakar di dalam bidang tertentu 
merupakan salah satu hal yang diperlukan oleh manusia dalam berbagai aspek kehidupan. Sistem pakar dibuat pada domain pengetahuan tertentu untuk suatu kepakaran tertentu yang mendekati kemampuan manusia di salah satu bidang. Sistem pakar mencoba mencari solusi yang memuaskan sebagaimana yang dilakukan seorang pakar.

Ada beberapa pertimbangan menggunakan sistem pakar. Dibawah ini sebagian dari pertimbangan yang utama :

1. Membantu melestarikan cagar alam pengetahuan dan keahlian pakar.

2. Jika keahlian adalah langka, mahal atau tak terbatas.

3. Mudah digunakan walaupun bukan seorang ahli.

\section{B. Tanaman Kelapa Sawit}

Menurut Putranto Adi (dalam Akim M.H.

Pardede, Novriyenni, 2016) Tanaman kelapa sawit adalah tanaman yang berbentuk pohon. Tingginya dapat mencapai 24 meter. Akar serabut tanaman kelapa sawit mengarah kebawah dan samping. Setelah itu juga dapat beberapa akar napas yang tumbuh mengarah kesamping atas untuk mendapatkan tambahan aerasi. Seperti jenis palma lainnya, daunnya tersusun majemuk menyirip. Daun bewarnah hijau tua dan pelepah bewarnah sedikit lebih muda. Penampilan agak mirip sedikit dengan tanaman salak, hanya saja dengan duri yang tidak terlalu keras dan tajam. Batang tanaman diselimutin dengan bekas pelepah hingga umur 12 tahun. Setelah umur 12 tahun pelepah yang mengiringi akan terlepas sehingga penampilan akan mirip dengan kelapa.

\section{Jenis-jenis Penyakit Tanaman Kelapa Sawit Adpun jenis-jenis penyakit tanaman kelapa} sawit adalah sebagai berikut (Akim M.H. Pardede, Novriyenni, 2016) :

1. Penyakit Busuk Pangkal Batang (Gonoderma Sp.)

2. Penyakit Busuk Tandan (Marasmius).

3. Penyakit Tajuk (crown deseases).

4. Penyakit Bercak Daun.

5. Penyakit Karat.

6. Penyakit Busuk Pucuk Kelapa Sawit.

7. Penyakit Cincin Merah (red ring disease).

8. Penyakit Daun Menguning.

9. Penyakit Akar.

\section{Teori Bayes}

Metode Bayes ini merupakan metode yang baik didalam mesin pembelanjaran berdasarkan data training, dengan menggunakan probabilitas bersyarat sebagai dasarnya (Rika Hamdani, 2016).

Menurut Sri Rahayu, (2013) metode bayes merupakan metode yang baik di dalam mesin pembelajaran berdasarkan data training, dengan menggunakan probabilitas bersyarat sebagai dasarnya. Metode bayes juga merupakan suatu metode untuk menghasilkan estimasi parameter dengan menggabungkan informasi dari sampel dan informasi lain yang telah tersedia sebelumnya.

Menurut Acihmah Sidauruk dan Ade Pujianto, (2017) teori bayes merupakan kaidah yang memperbaiki atau merevisi suatu probabilitas dengan cara memanfaatkan informasi tambahan. Maksudnya, dari probabilitas awal (prior probability) yang belum diperbaiki yang dirumuskan berdasarkan informasi yang tersedia saat ini, kemudian dibentuklan probabilitas berikutnya (posterior probability).

Bentuk teorema bayes untuk evidence tunggal E hipotesis tunggal $\mathrm{H}$ adalah :

$\mathrm{P}(\mathrm{H} \mid \mathrm{E})=\frac{\mathrm{P}(\mathrm{E} \mid \mathrm{H}) * \mathrm{P}(\mathrm{H})}{\mathrm{P}(\mathrm{E})}$

Keterangan :

$\mathrm{P}(\mathrm{H} \mid \mathrm{E})$ : Probabilitas hipotesis $\mathrm{H}$ terjadi jika evidence E terjadi.

$\mathrm{P}(\mathrm{E} \mid \mathrm{H})$ : Probabilitas muncul evidence $\mathrm{E}$ jika hipotesis H terjadi.

$\mathrm{P}(\mathrm{H})$ : Probabilitas hipotesis $\mathrm{H}$ tanpa memandang evidence apapun.

$\mathrm{P}(\mathrm{E})$ : Probabilitas evidence $\mathrm{E}$ tanpa memandang apapun.

Bentuk teorema bayes untuk evidence tunggal E dan hipotesis ganda $\mathrm{H} 1, \mathrm{H} 2, \ldots . ., \mathrm{Hn}$ adalah :

$$
\mathrm{P}(H 1 \mid E)=\frac{\mathrm{P}(\mathrm{E} \mid \mathrm{H} 1) \cdot P(H 1)}{\sum_{k=1}^{n} P(E \mid H 1) \cdot P(H 1)} \ldots \ldots \ldots \ldots
$$

Dimana :

$\mathrm{P}(\mathrm{Hi} \mid \mathrm{E})$ : probalitas hipotesis Hi terjadi jika evidence E terjadi.

$\mathrm{P}(\mathrm{E} \mid \mathrm{Hi})$ : probalitas muncul evidence $\mathrm{E}$, jika hipotesis Hi terjadi.

$\mathrm{P}(\mathrm{Hi}) \quad$ : probalitas hipotesis Hi tanpa memandang evidence apa pun.

$\mathrm{N} \quad$ : jumlah hipotesis yang terjadi.

Untuk evidence ganda E1, H2,..., Em dan hipotesis ganda $\mathrm{H} 1, \mathrm{H} 2, \ldots . . \mathrm{Hn}$ adalah :

$$
\begin{aligned}
& \mathrm{P}(H i \mid E 1 E 2 \ldots . . E m)= \\
& =\frac{\mathrm{P}(\mathrm{E} 1, \mathrm{E} 2 \ldots \mathrm{En} \mid \mathrm{H} 1) * P(H i)}{\sum_{k=1}^{n} p(E 1 E 2 \ldots . . E m \mid H k) * P(H k)} \ldots \ldots
\end{aligned}
$$

\section{E. $U M L$}

UML (Unified Modeling Language) merupakan sebuah notasi grafis, yang di dukung oleh metode tunggal, yang membantu dalam menggambarkan dan merancang sistem perangkat lunak, khususnya sistem perangkat lunak yang dibangun dengan modelberorientasi objek (Riska Audina, 2015).

\section{METODOLOGI PENELITIAN}

A. Rancangan Penelitian

Untuk menyusun penelitian ini, dilakukan 
penerapan metode penelitian dalam memperoleh datadata yang dibutuhkan sehingga penyusunan penelitian ini dapat diselesaikan dengan baik, dan sistematis.

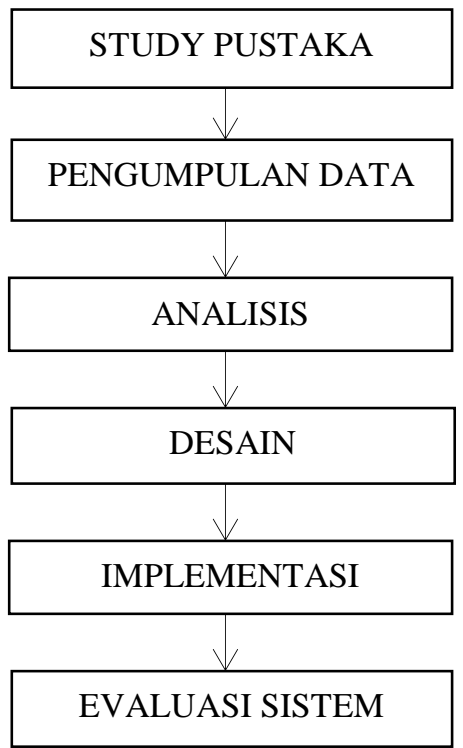

Gambar 1 Rancangan Penelitian

\section{B. Uraian Rancangan Penelitian}

\section{Study Pustaka}

Dilakukan untuk mendapatkan literatur yang mendukung penelitian ini. Literatur-literatur yang diambil dari penelitian-penelitian sebelumnya maupun dari jurnal-jurnal.

2. Pengumpulan Data

Pada bagian ini penulis melakukan pengumpulan data melalui observasi lapangan dengan bertanya kepada pakar yang mengetahui tentang penyakit tanaman kelapa sawit.

3. Analisis

Pada bagian ini penulis melakukan analisa pada penyakit tanaman kelapa sawit berdasarkan gejala yang dikumpulkan untuk satu penyakit, yang nantinya digunakan pada perancangan aplikasi.

4. Desain

Pada bagian ini penulis membuat desain dari sistem usulan berupa aplikasi sistem pakar berbasis android dalam bentuk use case diagram, class diagram, sequence diagram dan perancangan input.

5. Implementasi

Pada bagian ini penulis mengimplementasikan aplikasi sistem pakar berbasis android.

6. Evaluasi Sistem

Aplikasi yang sudah diimplementasikan akan dievaluasi untuk mengetahui kekurangankekurangan yang ada pada aplikasi yang penulis buat.

\section{ANALISA DAN PEMBAHASAN}

A. Analisa

1. Analisa Masalah

Dalam melakukan pembangunan aplikasi ini terdapat beberapa masalah dan faktor-faktor penting yang perlu diperhatikan. Faktor-faktor yang akan dianalisis tersebut, yaitu mengenai permasalahan bagaimana pengguna dapat mengetahui penyakit yang dialami tanaman kelapa sawit dari gejala penyakit yang dialami dengan menggunakan telepon selular. Hasil analisis ini akan dijadikan sebagian acuan dalam pembangunan aplikasi sistem pakar.

2. Analisa Sistem

Dari prosedur kerja yang telah dibuat, analisa sistem pakar penyakit tanaman kelapa sawit ini dilakukan melalui pengumpulan data dan analisis kebutuhan proses. Pengumpulan data yaitu, dilakukan untuk memperoleh beberapa informasi yang berkaitan dalam pembuatan aplikasi sistem pakar yaitu, berupa data gejala, data penyakit serta data sampel kasus.

3 Pengumpulan Data

Data-data yang diperoleh selama proses pengumpulan data terdiri dari data gejala, penyakit, aturan sistem pakar, berikut data-data yang didapat :

TABEL 1

\begin{tabular}{|c|c|}
\hline No & Penyakit \\
\hline Penyakit 1 & Busuk Pangkal Batang \\
\hline Penyakit 2 & Busuk Tandan \\
\hline Penyakit 3 & Tajuk \\
\hline Penyakit 4 & Bercak Daun \\
\hline Penyakit 5 & Karat \\
\hline Penyakit 6 & Busuk Pucuk Kelapa Sawit \\
\hline Penyakit 7 & Cincin Merah \\
\hline Penyakit 8 & Daun Menguning \\
\hline Penyakit 9 & Akar \\
\hline
\end{tabular}

TABEL 2

GEJALA PENYAKIT KELAPA SAWIT

\begin{tabular}{|c|l|}
\hline Kode & \multicolumn{1}{|c|}{ Gejala-gejala Penyakit } \\
\hline G1 & $\begin{array}{l}\text { Warna daun hijau kekuningan dan kusam, } \\
\text { layu, kekurangan air }\end{array}$ \\
\hline G2 & $\begin{array}{l}\text { Pertumbuhan daun bagian pucuk } \\
\text { terhambat sehingga permukaan tajuk daun } \\
\text { rata }\end{array}$ \\
\hline G3 & $\begin{array}{l}\text { Bentuk daun pada bagian pucuk lebih } \\
\text { pendek dari daun di bawahnya }\end{array}$ \\
\hline G5 & $\begin{array}{l}\text { Pertumbuhan pada bunga betina dan buah } \\
\text { terhambat, kebanyakan muncul bunga } \\
\text { jantan }\end{array}$ \\
\hline G6 & $\begin{array}{l}\text { Adanya rizomorf jamur berwarna putih } \\
\text { pada permukaan buah terutama di bagian } \\
\text { pangkal di dekat stalk }\end{array}$ \\
\hline G7 & $\begin{array}{l}\text { Terlihat helai daun mulai dari pertengahan } \\
\text { sampai ujung pelepah kecil - kecil }\end{array}$ \\
\hline G8 & $\begin{array}{l}\text { Terlihat keadaan helai daun sobek atau } \\
\text { tiadak ada sama sekali }\end{array}$ \\
\hline G9 & $\begin{array}{l}\text { banyak daun yang membengkok ke bawah } \\
\text { di tengah pelepahnya }\end{array}$ \\
\hline G10 & Keadaan daun kurang hijau \\
\hline
\end{tabular}




\begin{tabular}{|c|l|}
\hline Kode & \multicolumn{1}{|c|}{ Gejala-gejala Penyakit } \\
\hline G11 & $\begin{array}{l}\text { Terlihat bintik kuning pada daun tombak } \\
\text { atau yang telah membuka }\end{array}$ \\
\hline G12 & $\begin{array}{l}\text { Terlihat bercak lonjong dengan panjang 7- } \\
8 \text { mm berwarna coklat terang dengan tepi } \\
\text { kuning atau tidak }\end{array}$ \\
\hline G13 & $\begin{array}{l}\text { Bagian tengah bercak kadang kala tampak } \\
\text { berminyak }\end{array}$ \\
\hline G14 & $\begin{array}{l}\text { Beberapa bercak menyatu membentuk } \\
\text { bercak besar tak beraturan }\end{array}$ \\
\hline G15 & $\begin{array}{l}\text { Terlihat pembentukan karat berwarna } \\
\text { kemerahan pada pelepah-pelepah tua } \\
\text { (bagian bawah) }\end{array}$ \\
\hline G16 & $\begin{array}{l}\text { Terlihat seluruh daun pada pelepah- } \\
\text { pelepah bawah menjadi kering lalu mati }\end{array}$ \\
\hline G17 & $\begin{array}{l}\text { Terlihat janur berwarna pucat, condong } \\
\text { dan akhirnya patah }\end{array}$ \\
\hline G18 & $\begin{array}{l}\text { Terlihat dalam kurun waktu sedikit demi } \\
\text { sedikit daun bawah berwarna kuning } \\
\text { suram, tidak mengkilat, dan menjadi } \\
\text { coklat }\end{array}$ \\
\hline G19 & $\begin{array}{l}\text { Terlihat pembusukan di bagian pucuk atau } \\
\text { tunas bakal daun yang masih muda } \\
\text { sebelum tumbuh ke luar }\end{array}$ \\
\hline G20 & $\begin{array}{l}\text { Terlihat daun yang tumbuh semakin } \\
\text { mengecil }\end{array}$ \\
\hline G21 & $\begin{array}{l}\text { Terlihat bercak-bercak berwarna kuning } \\
\text { sampai jingga di petiol dan daun tombak }\end{array}$ \\
\hline G22 & $\begin{array}{l}\text { Munculnya cincin-cincin berkelir merah di } \\
\text { batang tanaman }\end{array}$ \\
\hline G23 & $\begin{array}{l}\text { Terlihat Bintik-bintik hitam yang } \\
\text { membentuk pola cincin tersebar di } \\
\text { sepanjang batang sawit }\end{array}$ \\
\hline G24 & $\begin{array}{l}\text { layunya daun hingga berubah menjadi } \\
\text { kecoklat-coklatan dan mengering }\end{array}$ \\
\hline G25 & $\begin{array}{l}\text { Terlihat belang-belang berkelir hijau dan } \\
\text { kuning di beberapa bagian tanaman sawit }\end{array}$ \\
\hline G27 & $\begin{array}{l}\text { Terlihat pertumbuhan tanaman menjadi } \\
\text { tidak normal, kerdil } \\
\text { Terlihat kondisi tanaman menjadi lemah } \\
\text { dan menjadi nekrosis (daun berubah warna } \\
\text { dari hijau menjadi kuning) }\end{array}$ \\
\hline
\end{tabular}

\section{Analisis Proses Perhitungan}

Perhitungan manual :

1. Penyakit (Penyakit 1) : Busuk Pangkal Batang

Jika probabilitas (Penyakit 1) adalah : 0,11

Jika probabilitas gejala memandang penyakit

adalah $\mathrm{G} 1: 1, \mathrm{G} 2: 1, \mathrm{G} 3: 1, \mathrm{G} 4: 1$

Keterangan :

a. Probabilitas penyakit $1=0,11$ di dapat dari penilaian yang diberi oleh peneliti untuk proses perhitungan dari tiap-tiap penyakit untuk mendapatkan nilai akhir dari penentuan penyakit yang dialami oleh tanaman kelapa sawit. b. Probailitas gejala $=1$ merupakan pemberian nilai bobot dari tiap-tiap gejala yang ada di sistem, nilai ini didapat dari pemberian peneliti untuk memudahkan proses perhitungan metode bayes.

Perhitungan nilai Bayes :

$\mathrm{P}($ Penyakit $1 \mid \mathrm{G} 1)=$

$\mathrm{P}(\mathrm{G} 1 \mid$ Penyakit 1$) * \mathrm{P}$ (Penyakit 1$)$

$\mathrm{P}(\mathrm{G} 1 \mid$ Penyakit 1$) * \mathrm{P}($ Penyakit 1$)+\mathrm{P}(\mathrm{G} 1 \mid$ Penyakit

2) * P (Penyakit 2) + P (G1 | Penyakit 3) * P (Penyakit

3) $+\mathrm{P}(\mathrm{G} 1 \mid$ Penyakit 4) * P (Penyakit 4) + P (G1 |

Penyakit 5) * P (Penyakit 5) + P (G1 | Penyakit 6) * P

(Penyakit 6) +

$\mathrm{P}(\mathrm{G} 1 \mid$ Penyakit 7$) * \mathrm{P}($ Penyakit 7$)+\mathrm{P}(\mathrm{G} 1 \mid$ Penyakit

8) * P (Penyakit 8$)+\mathrm{P}(\mathrm{G} 1 \mid$ Penyakit 9$) * \mathrm{P}($ Penyakit

9)

$=1 * 0,11$

$(1 * 0,11)+(0 * 0,11)+(0 * 0,11)+$

$(0 * 0,11)+(0 * 0,11)+(0 * 0,11)+$

$(0 * 0,11)+(0 * 0,11)+(0 * 0,11)$

$=\frac{0,11}{0,11}$

$=1$

$\mathrm{P}($ Penyakit $1 \mid \mathrm{G} 2)=$

$\mathrm{P}(\mathrm{G} 2 \mid$ Penyakit 1$) * \mathrm{P}($ Penyakit 1$)$

$\mathrm{P}(\mathrm{G} 2 \mid$ Penyakit 1$) * \mathrm{P}($ Penyakit 1$)+\mathrm{P}(\mathrm{G} 2 \mid$ Penyakit 2) * P (Penyakit 2$)+\mathrm{P}(\mathrm{G} 2 \mid$ Penyakit 3$) * \mathrm{P}$ (Penyakit

3) $+\mathrm{P}(\mathrm{G} 2 \mid$ Penyakit 4) $* \mathrm{P}($ Penyakit 4$)+\mathrm{P}(\mathrm{G} 2 \mid$

Penyakit 5) * $\mathrm{P}($ Penyakit 5$)+\mathrm{P}(\mathrm{G} 2 \mid$ Penyakit 6$) * \mathrm{P}$ (Penyakit 6) +

$\mathrm{P}(\mathrm{G} 2 \mid$ Penyakit 7$) * \mathrm{P}$ (Penyakit 7$)+\mathrm{P}(\mathrm{G} 2 \mid$ Penyakit 8) * P (Penyakit 8) + P (G2 | Penyakit 9) * P (Penyakit 9)

$=1 * 0,11$

$(1 * 0,11)+(0 * 0,11)+(0 * 0,11)+$

$(0 * 0,11)+(0 * 0,11)+(0 * 0,11)+$

$(0 * 0,11)+(0 * 0,11)+(0 * 0,11)$

$=\frac{0,11}{0,11}$

$=1$

$P($ Penyakit $1 \mid \mathrm{G} 3)=$

$\mathrm{P}(\mathrm{G} 10 \mid$ Penyakit 1$) * \mathrm{P}$ (Penyakit 1$)$

$\mathrm{P}(\mathrm{G} 3 \mid$ Penyakit 1$) * \mathrm{P}($ Penyakit 1$)+\mathrm{P}(\mathrm{G} 3 \mid$ Penyakit

2) * P (Penyakit 2$)+\mathrm{P}(\mathrm{G} 3 \mid$ Penyakit 3$) * \mathrm{P}($ Penyakit

3) $+\mathrm{P}(\mathrm{G} 3 \mid$ Penyakit 4$) * \mathrm{P}($ Penyakit 4$)+\mathrm{P}(\mathrm{G} 3 \mid$

Penyakit 5) *

$\mathrm{P}($ Penyakit 5$)+\mathrm{P}(\mathrm{G} 3 \mid$ Penyakit 6$) * \mathrm{P}($ Penyakit 6$)+$

$\mathrm{P}(\mathrm{G} 3 \mid$ Penyakit 7$) * \mathrm{P}($ Penyakit 7$)+\mathrm{P}(\mathrm{G} 3 \mid$ Penyakit

8) * P (Penyakit 8$)+\mathrm{P}(\mathrm{G} 3 \mid$ Penyakit 9$) * \mathrm{P}($ Penyakit 9)

$=1 * 0,11$

$(1 * 0,11)+(0 * 0,11)+(0 * 0,11)+$

$(0 * 0,11)+(0 * 0,11)+(0 * 0,11)+$

$(0 * 0,11)+(0 * 0,11)+(0 * 0,11)$

$=0,11$

$\overline{0,11}$

$=1$ 
$P($ Penyakit $1 \mid \mathrm{G} 4)=$

$\mathrm{P}(\mathrm{G} 4 \mid$ Penyakit 1$) * \mathrm{P}($ Penyakit 1$)$

$\mathrm{P}(\mathrm{G} 4 \mid$ Penyakit 1$) * \mathrm{P}($ Penyakit 1$)+\mathrm{P}(\mathrm{G} 4 \mid$ Penyakit 2) * P (Penyakit 2$)+\mathrm{P}(\mathrm{G} 4 \mid$ Penyakit 3$) * \mathrm{P}($ Penyakit 3) $+\mathrm{P}(\mathrm{G} 4 \mid$ Penyakit 4$) * \mathrm{P}($ Penyakit 4$)+\mathrm{P}(\mathrm{G} 4 \mid$ Penyakit 5) * P (Penyakit 5) + P (G4 | Penyakit 6) * $\mathrm{P}$ (Penyakit 6) +

$\mathrm{P}(\mathrm{G} 4 \mid$ Penyakit 7$) * \mathrm{P}($ Penyakit 7$)+\mathrm{P}(\mathrm{G} 4 \mid$ Penyakit 8) * P (Penyakit 8) + P (G4 | Penyakit 9) * P (Penyakit 9)

$$
\begin{aligned}
& =1 * 0,11 \\
& (1 * 0,11)+(0 * 0,11)+(0 * 0,11)+ \\
& (0 * 0,11)+(0 * 0,11)+(0 * 0,11)+ \\
& (0 * 0,11)+(0 * 0,11)+(0 * 0,11) \\
& =\frac{0,11}{0,11} \\
& =1
\end{aligned}
$$

Total Bayes $1=1+1+1+1=4$

2. Penyakit (Penyakit 2) : Busuk Tandan Jika probabilitas (Penyakit 2) adalah : 0,11 Jika probabilitas gejala memandang penyakit adalah G1 : 0, G2 : 0, G3 : 0, G4 : 0

Perhitungan nilai Bayes :

$P($ Penyakit $2 \mid \mathrm{G} 1)=$

$\mathrm{P}(\mathrm{G} 1 \mid$ Penyakit 2) * P (Penyakit 2)

$\mathrm{P}(\mathrm{G} 1 \mid$ Penyakit 1$) * \mathrm{P}($ Penyakit 2$)+\mathrm{P}(\mathrm{G} 1 \mid$ Penyakit 2) * P (Penyakit 2$)+\mathrm{P}(\mathrm{G} 1 \mid$ Penyakit 3$) * \mathrm{P}$ (Penyakit $3)+\mathrm{P}(\mathrm{G} 1 \mid$ Penyakit 4) * P (Penyakit 4) + P (G1 | Penyakit 5)*

$\mathrm{P}($ Penyakit 5) + P $(\mathrm{G} 1 \mid$ Penyakit 6$) * \mathrm{P}($ Penyakit 6) + $\mathrm{P}(\mathrm{G} 1 \mid$ Penyakit 7$) * \mathrm{P}($ Penyakit 7$)+\mathrm{P}(\mathrm{G} 1 \mid$ Penyakit 8) * P (Penyakit 8$)+$ P (G1 | Penyakit 9$) * \mathrm{P}($ Penyakit 9)

$$
\begin{aligned}
& =0 * 0,11 \\
& (0 * 0,11)+(0 * 0,11)+(0 * 0,11)+ \\
& (0 * 0,11)+(0 * 0,11)+(0 * 0,11)+ \\
& (0 * 0,11)+(0 * 0,11)+(0 * 0,11) \\
& =\frac{0}{0} \\
& =0
\end{aligned}
$$

$\mathrm{P}($ Penyakit $2 \mid \mathrm{G} 2)=$ $\mathrm{P}(\mathrm{G} 2 \mid$ Penyakit 2$) * \mathrm{P}($ Penyakit 2)

$\mathrm{P}(\mathrm{G} 2 \mid$ Penyakit 2$) * \mathrm{P}($ Penyakit 1$)+\mathrm{P}(\mathrm{G} 2 \mid$ Penyakit 2) * P (Penyakit 2$)+\mathrm{P}(\mathrm{G} 2 \mid$ Penyakit 3$) * \mathrm{P}($ Penyakit $3)+\mathrm{P}(\mathrm{G} 2 \mid$ Penyakit 4$) * \mathrm{P}($ Penyakit 4$)+\mathrm{P}(\mathrm{G} 2 \mid$ Penyakit 5) *

$\mathrm{P}($ Penyakit 5$)+\mathrm{P}(\mathrm{G} 2 \mid$ Penyakit 6$) * \mathrm{P}($ Penyakit 6$)+$ $\mathrm{P}(\mathrm{G} 2 \mid$ Penyakit 7$) * \mathrm{P}($ Penyakit 7$)+\mathrm{P}(\mathrm{G} 2 \mid$ Penyakit 8) * P (Penyakit 8$)+\mathrm{P}(\mathrm{G} 2 \mid$ Penyakit 9$) * \mathrm{P}($ Penyakit 9)

$=0 * 0,11$

$(0 * 0,11)+(0 * 0,11)+(0 * 0,11)+$

$(0 * 0,11)+(0 * 0,11)+(0 * 0,11)+$

$(0 * 0,11)+(0 * 0,11)+(0 * 0,11)$

$=\frac{0}{0}$
$=0$

$P($ Penyakit $2 \mid \mathrm{G} 3)=$

$\mathrm{P}(\mathrm{G} 3 \mid$ Penyakit 2$) * \mathrm{P}($ Penyakit 2$)$

$\mathrm{P}(\mathrm{G} 3 \mid$ Penyakit 2$) * \mathrm{P}($ Penyakit 1$)+\mathrm{P}(\mathrm{G} 3 \mid$ Penyakit 2) * P (Penyakit 2) + P (G3 | Penyakit 3$) * \mathrm{P}($ Penyakit $3)+\mathrm{P}(\mathrm{G} 3 \mid$ Penyakit 4) * P (Penyakit 4) + P (G3 |

Penyakit 5) * $\mathrm{P}($ Penyakit 5$)+\mathrm{P}(\mathrm{G} 3 \mid$ Penyakit 6$) * \mathrm{P}$ (Penyakit 6) +

$\mathrm{P}(\mathrm{G} 3 \mid$ Penyakit 7$) * \mathrm{P}($ Penyakit 7$)+\mathrm{P}(\mathrm{G} 3$ | Penyakit 8) * P (Penyakit 8$)+\mathrm{P}(\mathrm{G} 3 \mid$ Penyakit 9$) * \mathrm{P}$ (Penyakit 9)

$$
\begin{aligned}
& =0 * 0,11 \\
& (0 * 0,11)+(0 * 0,11)+(0 * 0,11)+ \\
& (0 * 0,11)+(0 * 0,11)+(0 * 0,11)+ \\
& (0 * 0,11)+(0 * 0,11)+(0 * 0,11) \\
& =\frac{0}{0} \\
& =0
\end{aligned}
$$

$\mathrm{P}($ Penyakit $2 \mid \mathrm{G} 4)=$ $\mathrm{P}(\mathrm{G} 4 \mid$ Penyakit 2) * P (Penyakit 2)

$\mathrm{P}(\mathrm{G} 4 \mid$ Penyakit 2$) * \mathrm{P}($ Penyakit 1$)+\mathrm{P}(\mathrm{G} 4 \mid$ Penyakit 2) $* \mathrm{P}($ Penyakit 2$)+\mathrm{P}(\mathrm{G} 4 \mid$ Penyakit 3$) * \mathrm{P}($ Penyakit $3)+\mathrm{P}(\mathrm{G} 4 \mid$ Penyakit 4$) * \mathrm{P}($ Penyakit 4$)+\mathrm{P}(\mathrm{G} 4 \mid$ Penyakit 5)*

$\mathrm{P}($ Penyakit 5) + P (G4 | Penyakit 6) * P (Penyakit t6) $+\mathrm{P}(\mathrm{G} 4 \mid$ Penyakit 7$) * \mathrm{P}$ Penyakit 7$)+\mathrm{P}(\mathrm{G} 4 \mid$ Penyakit 8$) * \mathrm{P}($ Penyakit 8$)+\mathrm{P}(\mathrm{G} 4 \mid$ Penyakit 9$) * \mathrm{P}$ (Penyakit 9)

$$
\begin{aligned}
& =0 * 0 \\
& (0 * 0,11)+(0 * 0,11)+(0 * 0,11)+ \\
& (0 * 0,11)+(0 * 0,11)+(0 * 0,11)+ \\
& (0 * 0,11)+(0 * 0,11)+(0 * 0,11) \\
& =\frac{0}{0} \\
& =0
\end{aligned}
$$

Total Bayes $1=0+0+0+0=0$

Hasil $=$ Total Bayes $1+$ Total Bayes 2

$=4+0$

$=4$

Maka perhitungan probabilitas penyakitnya adalah :

1. Busuk Pangkal Batang (Penyakit 1)

$=4 / 4 * 100 \%=100 \%$

2. Busuk Tandan (Penyakit 2)

$=0 / 4 * 100 \%=0 \%$

\section{B. Desain Sistem}

Desain sistem dalam sistem pakar ini dibagi menjadi beberapa subsistem, yaitu perancangan Unified Modeling Language (UML), perancangan antarmuka sistem (user interface). UML digunakan untuk merancang setiap proses yang akan dilakukan oleh sistem. Dalam perancangan sistem ini, terdapat empat diagram UML yang akan digunakan sesuai dengan kebutuhan sistem, yaitu: 


\section{Use Case Diagram user}

Pada sistem pakar yang dibangun hanya melibatkan satu aktor yaitu user. User dalam hal ini yaitu pengguna sistem, bukan perancang sistem. Use case diagram dalam sistem pakar ini terlihat pada Gambar 4.1.

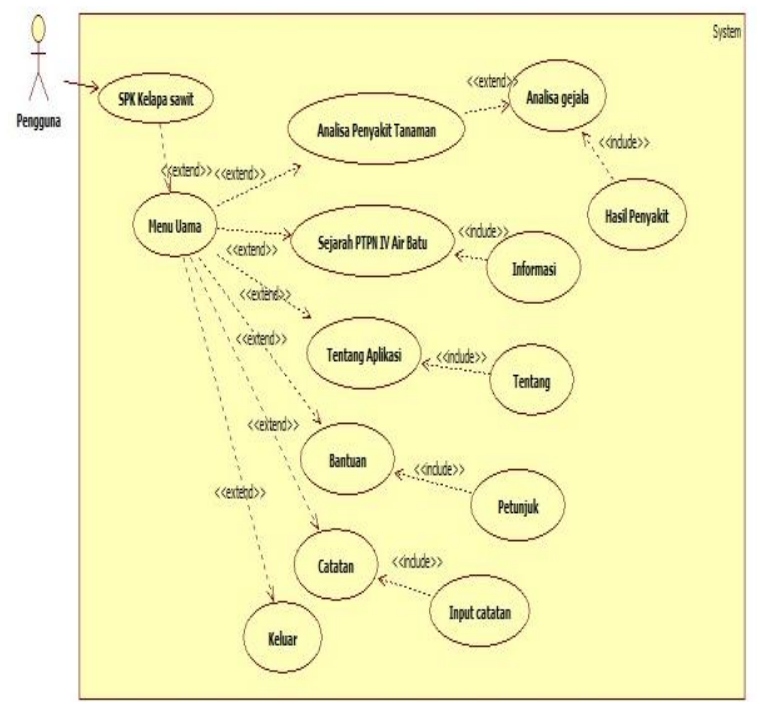

Gambar 2 Use Case Diagram

Dari Gambar 2 terlihat user dapat melakukan beberapa aktifitas yaitu analisa penyakit tanaman, Sejarah PTPN VI Air Batu, Tentang Aplikasi, Bantuan, dan Catatan. Proses aktifitas hasil diagnosa merupakan include atau bagian dari konsultasi, oleh karena itu user terlebih dahulu harus melakukan proses analisa. Proses analisa dilakukan dengan memilih gejala-gejala yang dialami, sehingga hasil diagnosa yang diharapkan sesuai dengan gejala yang dialami.

\section{Class Diagram}

Class diagram menggambarkan struktur sistem dari segi pendefinisian kelas-kelas yang akan dibuat untuk membangun sistem. Class diagram yang diusulkan sebagai berikut:

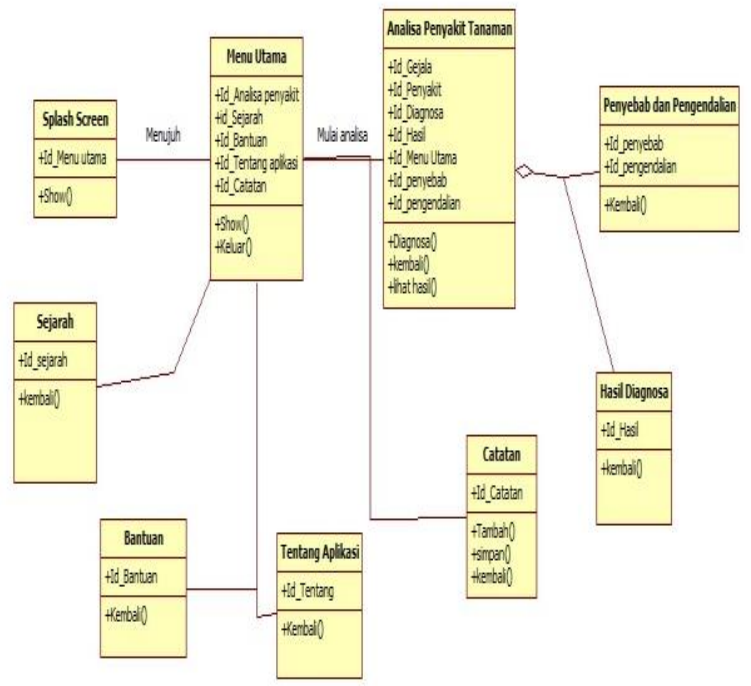

Gambar 3. Class Diagram

\section{Uji Coba dan Evaluasi}

Sebelum aplikasi diterapkan, maka aplikasi harus bebas dari kesalahan. Perlu dilakukan pengujian untuk menemukan kesalahan yang mungkin dapat terjadi. Tahap ini dilakukan agar aplikasi dapat terus digunakan dan berjalan dengan baik. Pelaksanaan aplikasi diterapkan dengan testing aplikasi yang telah dibangun, apakah yang dibangun sudah sesuai dengan harapan, pada tahap ini jika sistem yang dikembangkan belum sesuai dengan yang diharapkan maka penulis melakukan revisi terhadap aplikasi. Pengujian aplikasi dilakukan dengan meode blackbox testing. Pengujian dilakukan dengan menjalankan aplikasi dan melihat aplikasi ini apakah sesuai dengan domain masalah.

\section{Pembahasan}

1. Tampilan Icon

Tampilan Icon merupakan tampilan awal sebelum masuk ke aplikasi. Tampilan icon yang telah di install pada emulator akan tampak pada gambar dibawah ini.

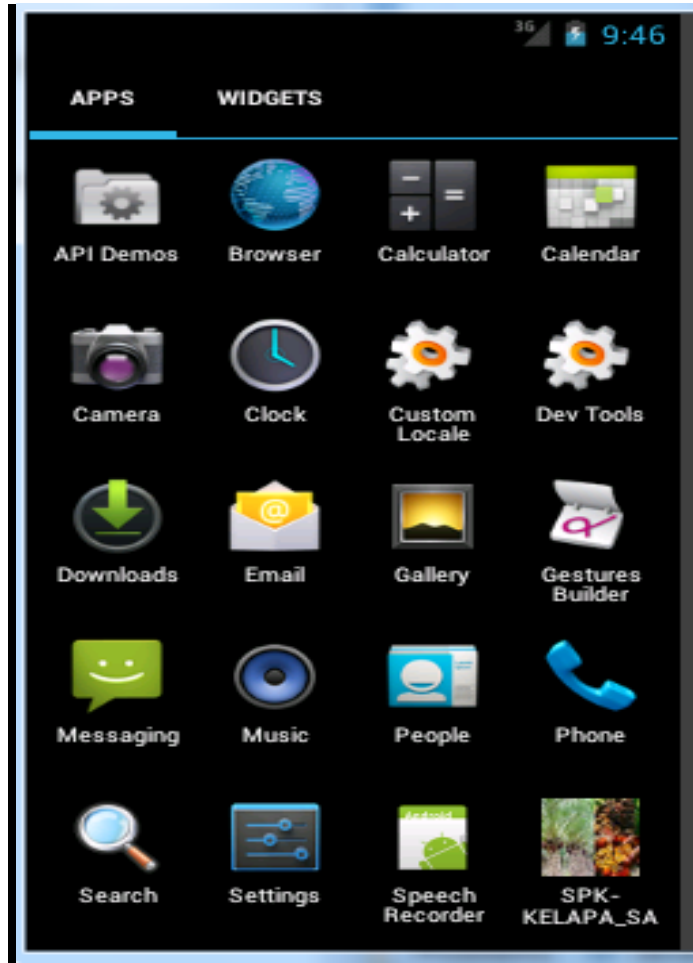

Gambar 4. Tampilan Icon

2 Tampilan Splash Screen

Splash screen merupakan halaman pertama kali muncul saat aplikasi dijalankan. Setelah melakukan loading pada halaman spalsh screen maka aplikasi akan memunculkan halaman Menu Utama. Gambar di bawah ini merupakan tampilan dari halaman splash screen saat aplikasi pertama kali di jalankan. 


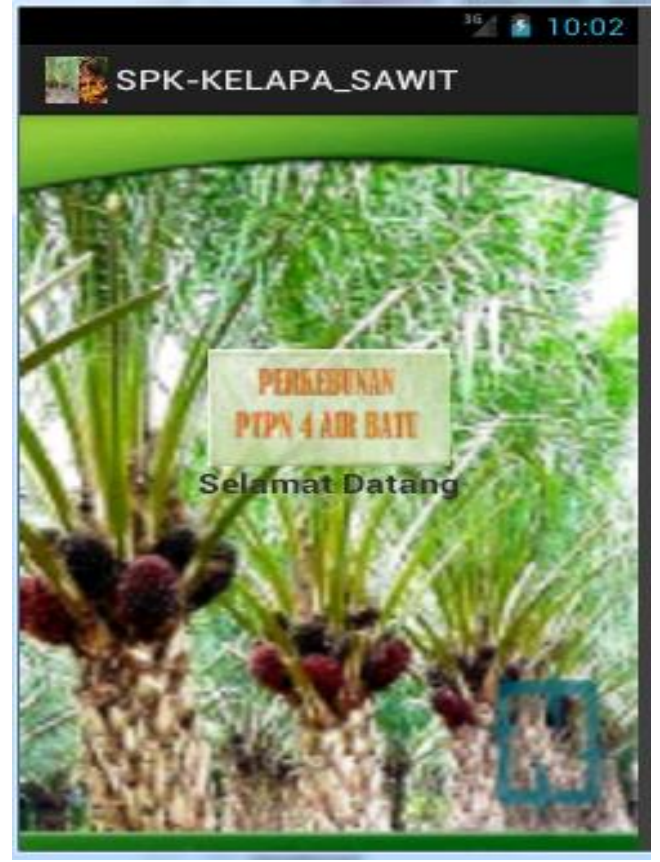

Gambar 5. Halaman Splash Screen

3. Tampilan Menu Utama

Menu Utama merupakan tampilan utama setelah splash screen selesai , di dalam menu utama ini terdapat menu yang digunakan dalam aplikasi ini. Menu utama merupakan navigasi untuk menuju ke menu-menu yang lain. Di bawah ini tampilan menu utama.

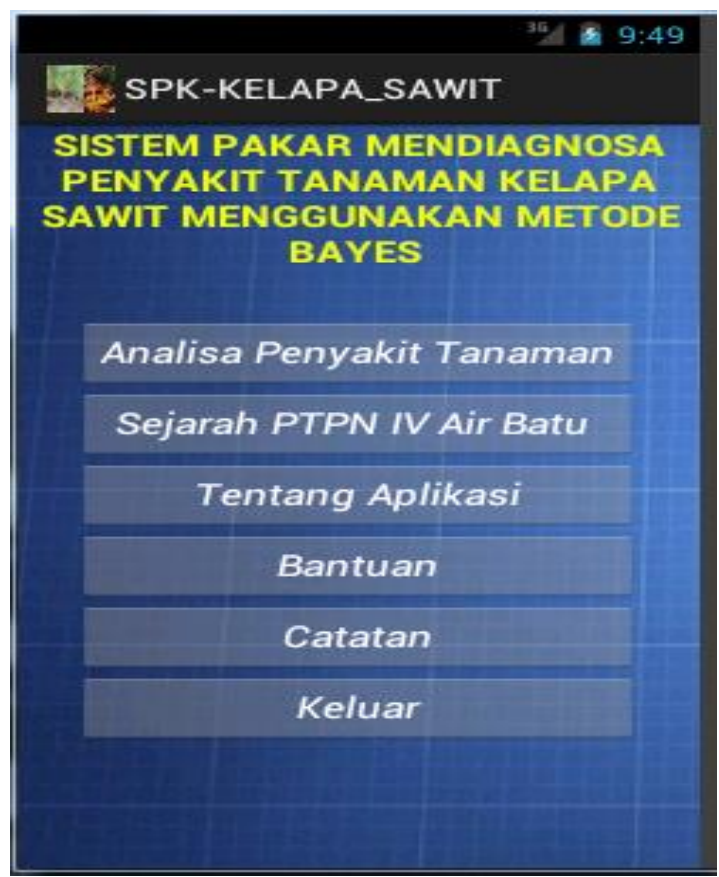

Gambar 6. Tampilan Menu Utama

4. Tampilan Menu Analisa Penyakit Tanaman

Menu analisa penyakit tanaman merupakan menu yang akan tampil setelah anda berada di menu utama. Menu ini digunakan untuk memperoses gejala- gejala yang dialami tanaman, Di bawah ini tampilan menu analisa dari aplikasi yang dibangun.

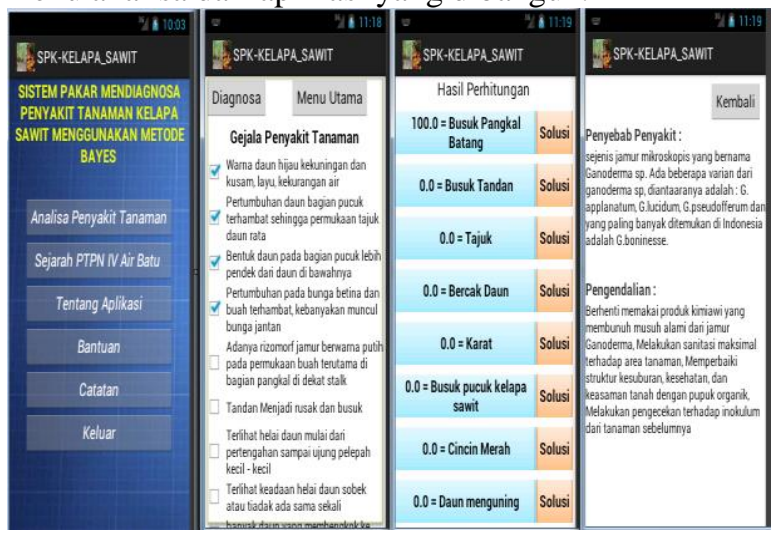

Gambar 7. Tampilan Menu Analisa Penyakit Tanaman

5. Tampilan Menu Sejarah PTPN IV Air Batu Menu sejarah berisikan keterangan tentang PTPN IV air batu, dibawah ini tampilan menu sejarah PTPN IV air batu.

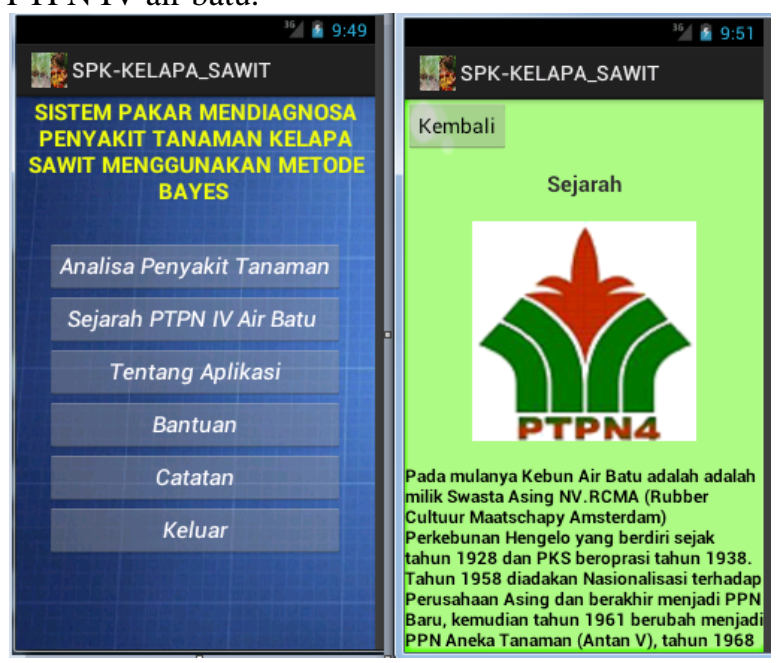

Gambar 8. Tampilan Menu Sejarah PTPN IV Air Batu

6. Tampilan Menu Tentang Aplikasi

Menu tentang aplikasi berisikan penjelasan tentang tujuan aplikasi ini di bangun, berikut ini tampilan dari menu tentang aplikasi. 


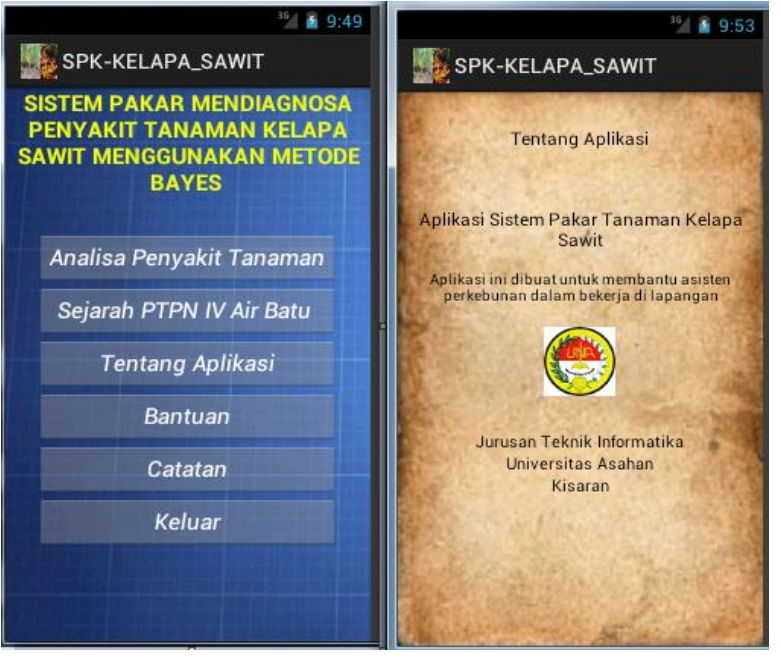

Gambar 9. Tampilan Menu Tentang Aplikasi

\section{Tampilan Menu Bantuan}

Pada menu ini aplikasi akan menampilkan bantuan cara menggunakan aplikasi. Gambar berikut ini tampilan dari menu bantuan.

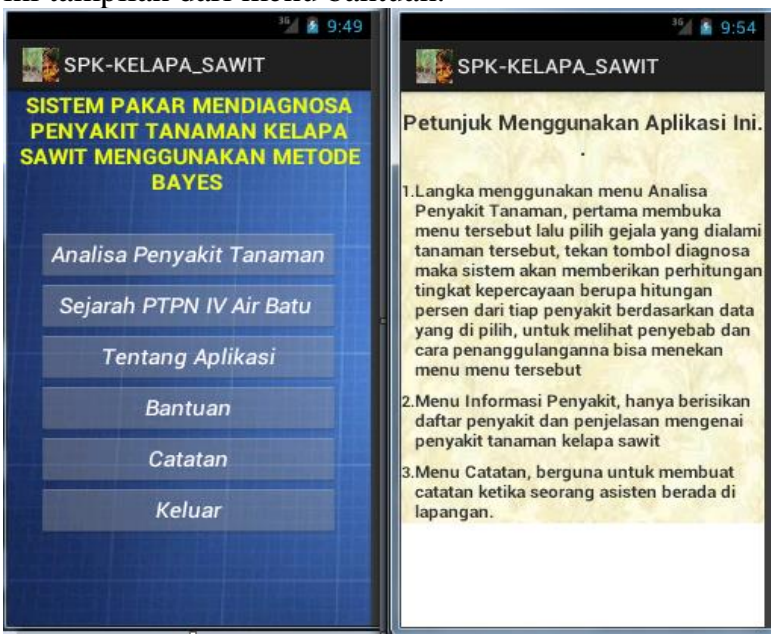

Gambar 10. Tampilan Menu Bantuan

\section{Tampilan Menu Catatan}

Pada menu ini nantinya digunakan untuk menginputkan catatan asisten perkebunan saat berada di lapangan.

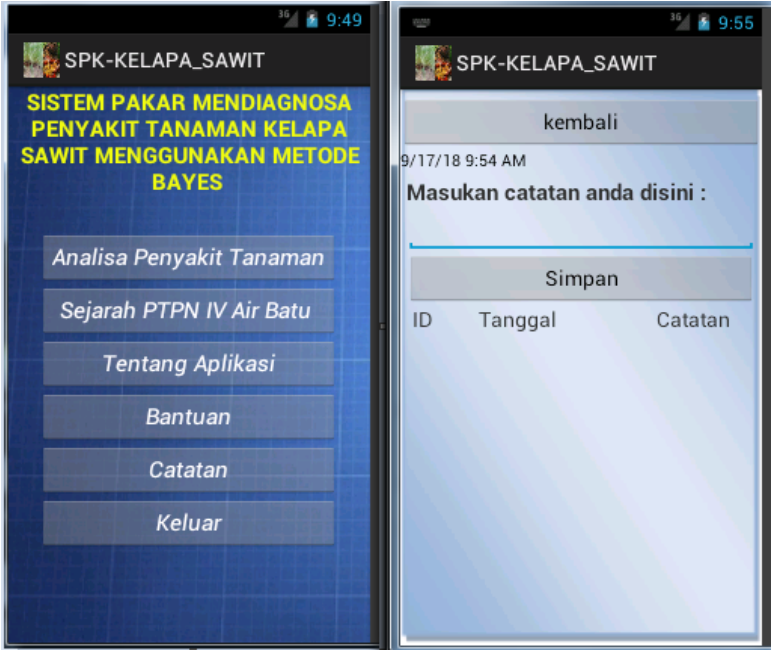

Gambar 11. Tampilan Menu Catatan V. PENUTUP

A. Kesimpulan

Dari hasil pembahasan pada bab-bab yang telah diuraikan sebelumnya, maka penulis mengambil kesimpulan sebagai berikut :

1. Untuk merancang aplikasi sistem pakar mendiagnosa penyakit tanaman kelapa sawit ini penulis menggunakan bahasa pemrograman android dengan java eclipse juno sehingga nantinya aplikasi ini dapat digunakan di lapangan dengan bantuan handphone android.

2. Untuk mengenali jenis penyakit tanaman kelapa sawit pengguna harus memilih gejala berdasarkan yang terjadi pada tanaman sehingga sistem dapat memproses gejala menggunakan algoritma bayes yang sudah di tanamkan ke program.

\section{B. Saran}

Saran yang dapat diberikan oleh Penulis atas perancangan aplikasi ini adalah sebagai berikut :

1. Penggunaan jQuery Mobile pada aplikasi harus mempertimbangkan masalah sumber daya perangkat bergerak, terutama pada ukuran layar. Sebab ada banyak model smartphone dengan berbagai ukuran layar. Jadi dalam mendesain harus menyesuaikan ukuran layar yang paling kecil.

2. Perlu dilakukan pengembangan lebih lanjut mengenai bagaimana membuat agar aplikasi ini dapat diterapkan di sistem operasi. Misalnya Blackberry, iOS, Widows Phone.

\section{DAFTAR PUSTAKA}

[1] Acihmah Sidauruk dan Ade Pujianto, 2017. "Sistem Pakar Diagnosa Penyakit Tanaman Kelapa Sawit Menggunakan Teorema Bayes". Jurnal Ilmiah DASI Vol. 18 No. 1.

[2] Akim M.H. Pardede, Novriyenni, 2016. "Perancangan Sistem Pakar Diagnosa Penyakit 
Tanaman Kelapa Sawit Dengan Metode Bayes Study Kasus Pt.Ukindo Blankahan Estate”. Jurnal KAPUTAMA, Vol.10 No.1.

[3] Eli Rosmita Ritonga dan Muhammad Dedi Irawan, 2017. Sistem Pakar Diagnosa Penyakit Paru-Paru Pada Anak Dengan Metode DempsterShafer. Journal of Computer Engineering, System And Science. Vol. 2. No.1.

[4] Rika Hamdani, 2016. "Penerapan Metode Bayes Dalam Mendiagnosa Gangguan Perkembangan Pada Anak”. Jurnal Mantik Penusa. Vol.20 No.1.

[5] Riska Audina, 2015. "Aplikasi Informasi Kegiatan Mahasiswa di Fakultas Ilmu Terapan Uniiversitas Telkom Berbasis Android dan SMS Broadcast". e-Proceeding of Applied Science : Vol.1. No.3.

[6] Siti Mujilahwati,2014. "Diagnosa Penyakit Tanaman Hias Menggunakan Metode Certainty Factor Berbasis Web”. Jurnal Teknik. Vol. 6. No. 2.

[7] Sri Rahayu, 2013. "Sistem Pakar Untuk Mendiagnosa Penyakit Gagal Ginjal Dengan Menggunakan Metode Bayes”. Pelita Informatika Budi Darma. Vol.4 No.3. 